\title{
AFRICA REVIEW \\ AN UP-TO-DATE GEOGRAPHICAL, HISTORICAL, POLITICAL AND ECONOMIC SUMMARY OF THE AFRICAN COUNTRIES
}

Prepared by: $\quad$ F. Pauwels, P. Van Damme, D. Theeten, Chr. De Keyser, S. Hoste, P. Wymeersch

\section{SENEGAL}

1. Official name: Republic of Senegal

République du Sénégal

2. Geography:

2.1. Situation: on the west coast of Africa, between $12^{\circ} 19^{\prime} \mathrm{N}$ and $16^{\circ} 42^{\prime} \mathrm{N}$, $11^{\circ} 20^{\prime} \mathrm{W}$ and $17^{\circ} 32^{\prime} \mathrm{W}$.

2.2. Total area: $196,720 \mathrm{~km}^{2}$.

2.3. Natural regions: the relief of Senegal is generally flat or gently rolling. Only in the southeastern Fouta Djalon upland, hills above $200 \mathrm{~m}$ are found. The country is crossed by several big rivers as the Senegal (northern border), Saloum, Gambie and Casamance. The southern part is almost isolated from the rest of Senegal by the Gambian territory.

2.4. Climate: tropical to semi-arid. The annual rainfall is fairly constant in the south and rather variable in the north. The following three anticyclones influence the climate: the Azores gives rise to the northerly marine wind from the Atlantic, the St. Helena brings the southeasterly rainbearing monsoon and the North African anticyclone causes the hot dry Harmattan wind, blowing from the northeast. 


\section{SENEGAL}

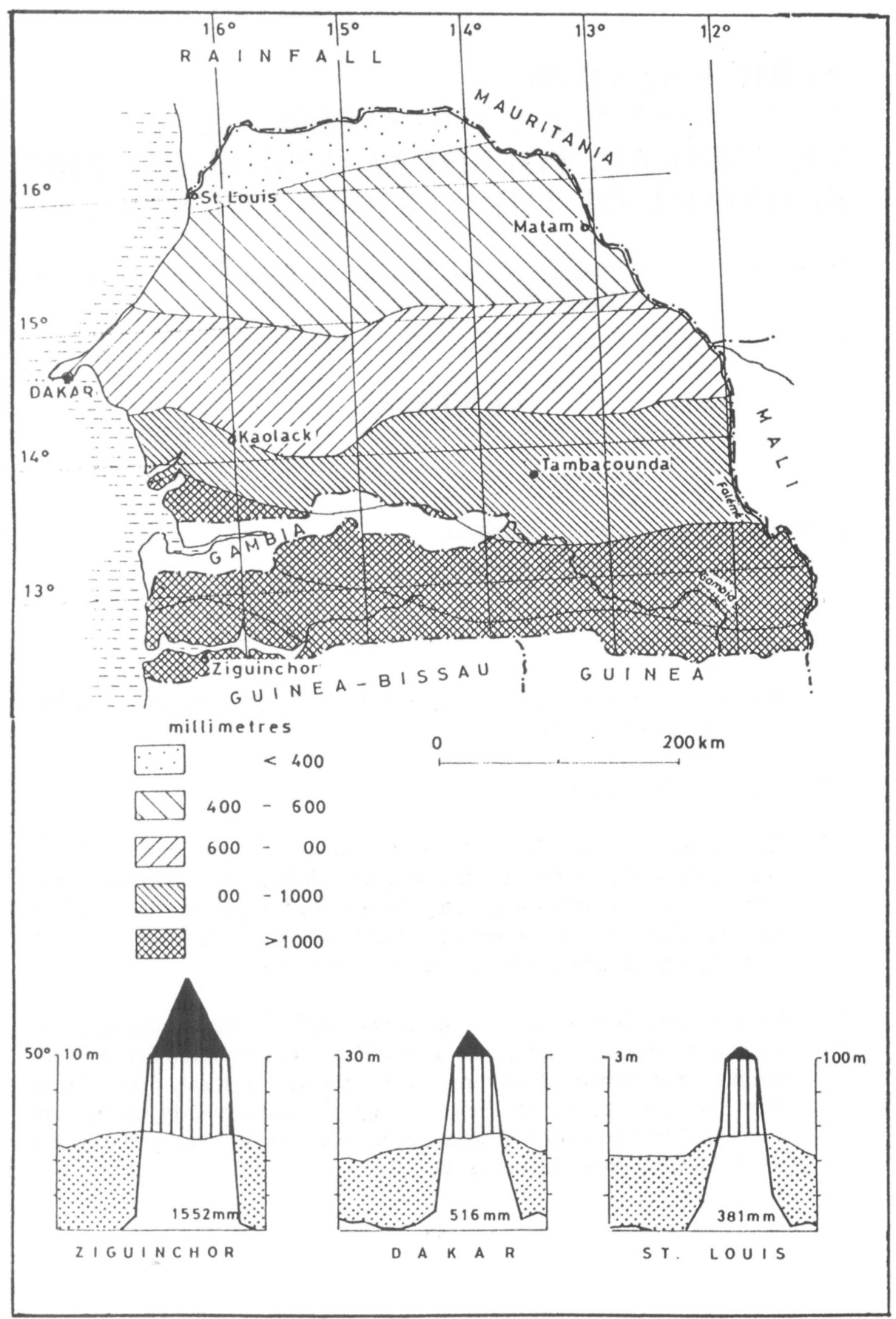




\section{Population:}

3.1. Total population: $7.9 \mathrm{mln}$ (1991), urban population: $38 \%$.

3.2. Population density: 36 per $\mathrm{km}^{2}$.

3.3. Population growth rate: $3.1 \%$ (1991).

3.4. Capital: DAKAR, $1.382 \mathrm{mln}$ inh. (1991).

3.5. Languages:French (official), Bassari, Diola, Fulfulde, Lebu, Malinke, Mandingo, Serer, Soninke, Tocolor, Wolof.

3.6. Religion: Muslim (Sunni) 91\%, Christians 6\%, Traditional beliefs 3\%.

4. History:

The banks of the Senegal river were inhabited by the ethnic groups of the Uolof (1/3 of the population), the Fulani and the Tukeler. Through contacts with their Arabic neighbours, Islam had become the main religion. In the 17 th century, the French occupied the region and incorporated it in the Atlantic slave trade for goods. Several local kings fought a guerilla war against the French unsuccessfully. In 1892 the French finally "pacified" the region. After World War I the concept of "négritude" together with it's driving force Léopold Senghor, opened the way to create their own political definition, away from the French imposed cultural patterns. In 1959 Senegal, French Sudan and Mali formed the Federation of Mali. When given independence in 1960, Senegal decides to become a separate republic with Senghor as the first President. He remained Head of State till 1981 when he stepped down. Abdou Diouf assumed the presidency. In 1982 Senegal and Gambia formed the Confederation of Senegambia which Diouf suspended in 1989. In the 80's the country was several times stricken with violent outburst of ethnic unrest along it's borders with Mauritania.

\section{Nature of political system:}

The Constitution was promulgated on 7 march 1963. In september 1991 several amendments were voted. The president is elected by direct universal suffrage for a seven-year term (only once renewable). He appoints the prime-minister who chooses his ministers. The National Assembly can remove the president from 


\section{SENEGAL}

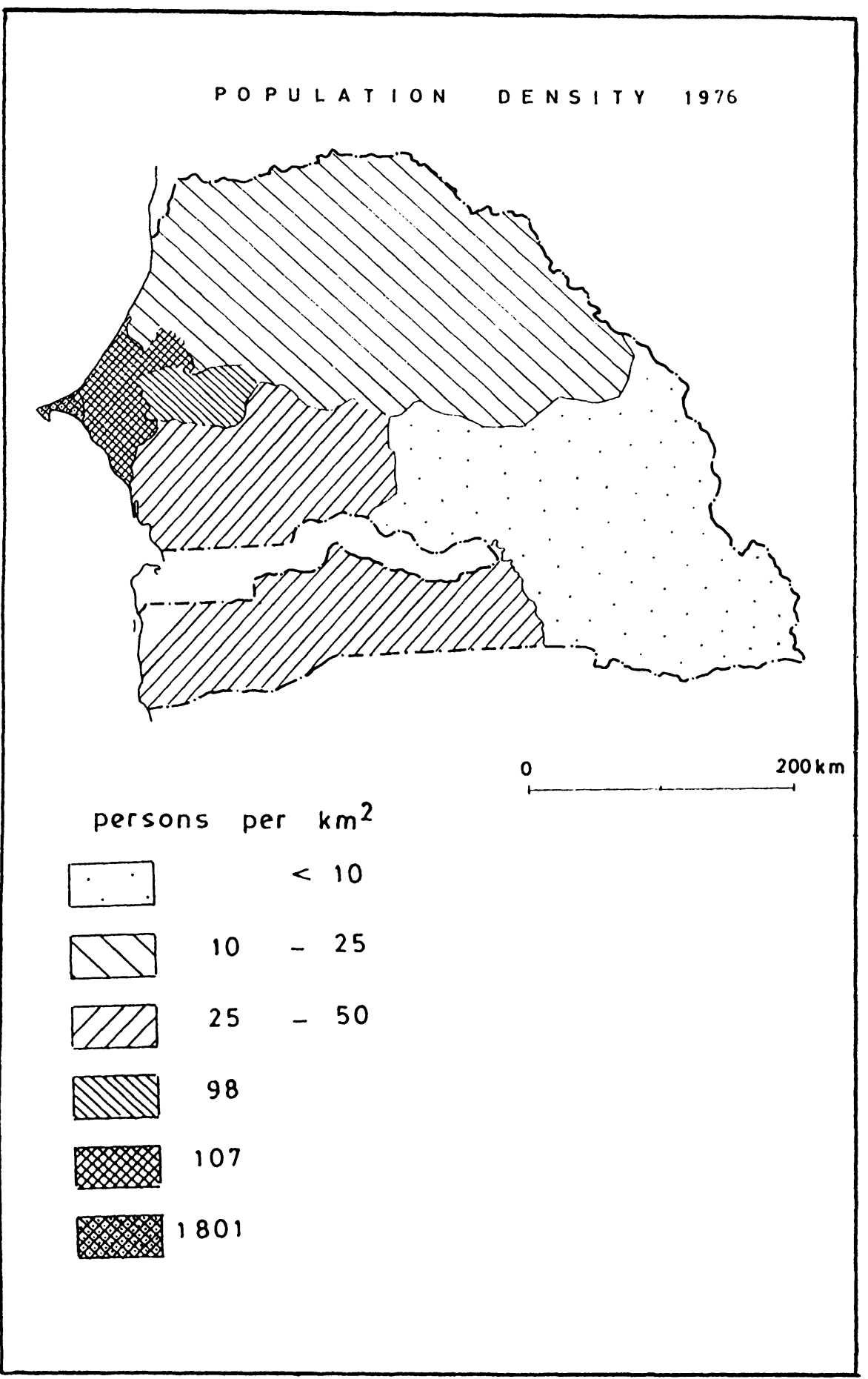


power with a 3/5 majority. The National Assembly is chosen by direct universal suffrage for five years and consists of 120 members. The Supreme Court may decide over the constitutionality of a draft law. There is no limit on the number of political parties.

\section{Economy:}

GDP: agriculture: $22 \%$, industry: $29 \%$, services: $49 \%$ (1991).

Employment: agriculture: $81 \%$, industry: $6 \%$, services: $13 \%$ (1980).

\subsection{Mining:}

Mainly calciumphosphates and aluminiumphosphates, further rutile, zircon, titan and salt.There are vast reserves of iron, zinc, and copper detected and petroleum exploitation has started in the early eighties.

\subsection{Agriculture:}

$27 \%$ of the total area is arable land or cultivated with permanent crops (1984). Major food crops are millet, sorghum and rice (increasing production in recent years). Other food crops in order of importance are maize, cassava, cowpea, sweet potato and fonio. Groundnuts are the leading cash crop, followed by cotton, oil palm and sugar-cane. Groundnuts are grown throughout the country, integrated in the traditional farming system. In the Cap Vert and Dakar regions, vegetable production has become very important.

\subsection{Livestock:}

$29 \%$ of the total area is permanent pasture (1984). Cattle (2.33 mln in 1982) has significant social function and is kept by both nomadic and sedentary farmers. In the north Zebu-types, which are not resistant against trypanosomiasis, are the principal breed. The N'Dama breed is predominant in the south. Sheep and goats $(3.36 \mathrm{mln})$ are widespread and often kept in association with cattle. 


\section{SENEGAL}

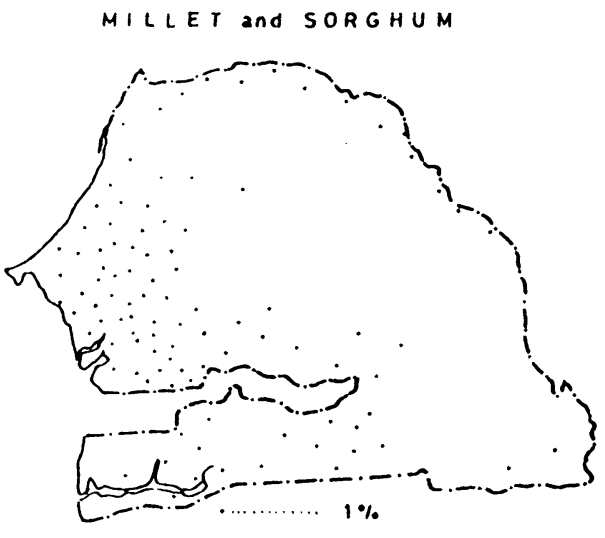

MAIZE and MANIOC
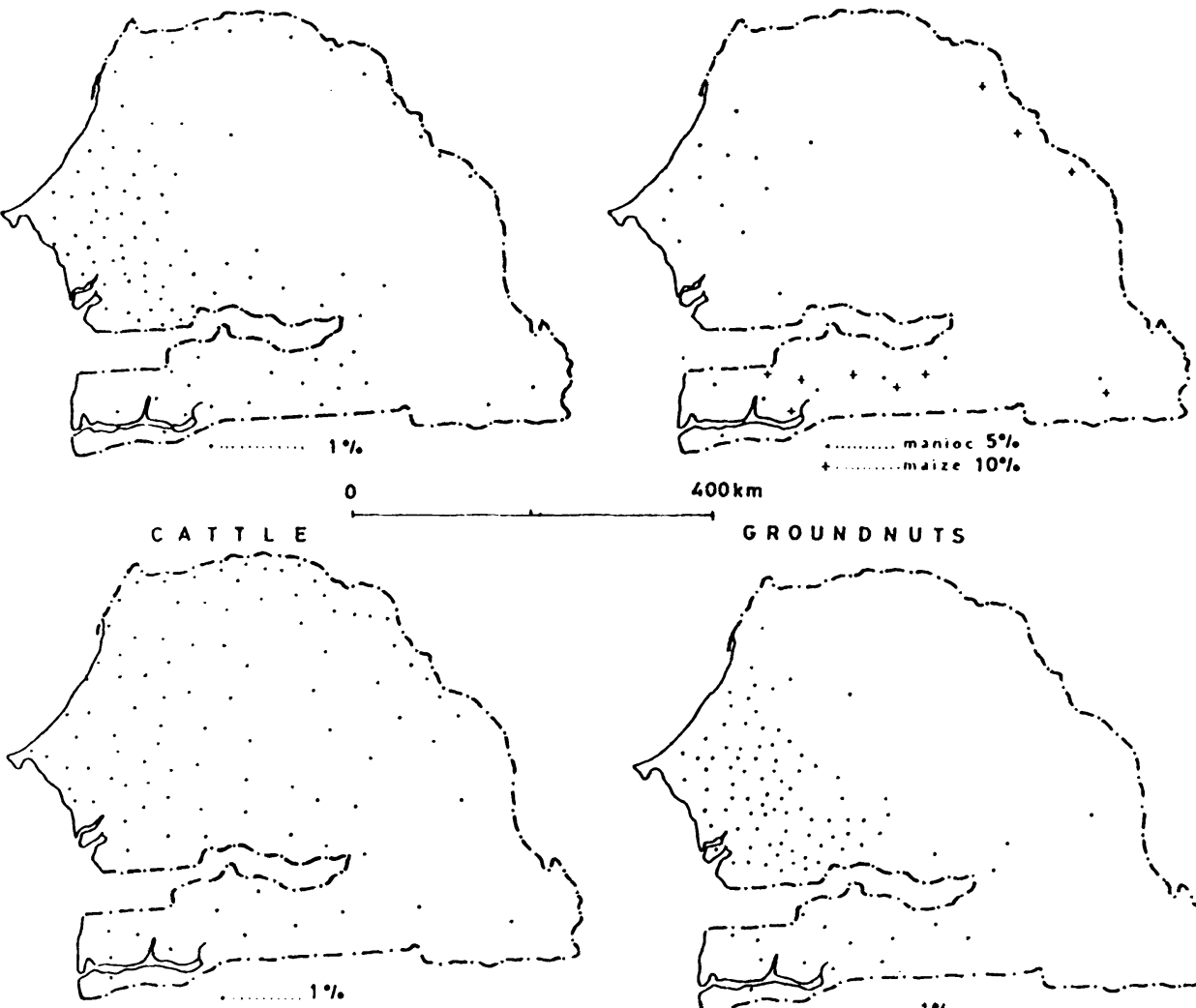

$400 \mathrm{~km}$

GROUNDNUTS

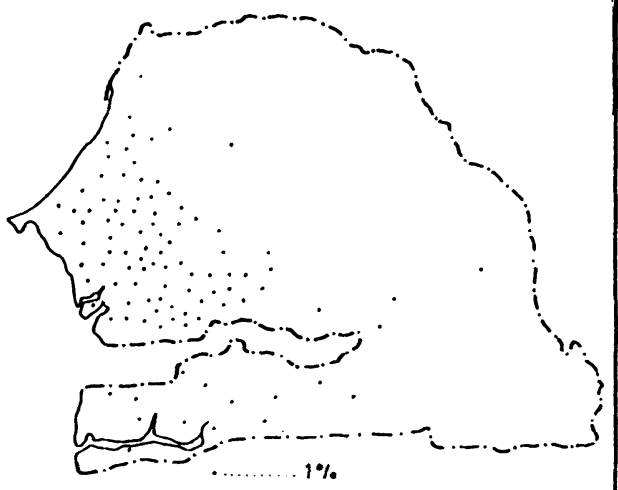

1 food crops: sorghum, millet 2 food crops: millet, groundnut 3 mixed farming

4 nomadic pastoralism

5 floodland rice fields

6 market gardening

7 food crops: maize, millet, groundnut, rice in the valleys 
6.4. Forestry and woodland:

$30 \%$ of the total area (1984). In the northern region the natural vegetation cover has disappeared. Throughout the country baobabs (Adansonia digitata) are associated with acacias and Combretum bush. The southern plains carry dry sudan woodland with dimbo (Cordyla pinata), ven (Pterocarpus eunaceus) and locust bean (Parkia biglobosa). In Casamance the man-made forest consists of Tectona grandis (teak) and Gmelina arborea. The annual production of gum arabic, from Acacia senegalensis amounts to approx. $10000 \mathrm{t}$. Along the rivers in the south there are important mangrove forests.

\subsection{Fishery:}

The coastal waters of Senegal are among the richest fishing grounds in West Africa (tuna and sardines in deep waters, shrimps, sole and gilthead near the coast). The fish consumption is very high ( $50 \mathrm{~kg}$ per capita) and recent investments made an annual catch of up to $350000 \mathrm{t}$ possible.

6.6. Industry:

The food industry is the most important with groundnut oil mills, flour mills, canning factories, sugar refineries and tobacco maim. The importance of the textile industry is decreasing while petroleum, tourism and chemical industries are growing quickly.

6.7. Weights, measures and currency:

$\mathrm{kg}$, meter

1 CFA Franc (CFA Fr) $=100$ centimes

1 US $\$=278.9$ CFA Fr (March 1992)

\section{Trade:}

Total exports amount to $526 \mathrm{mln}$ US \$ (1985), mostly groundnuts and groundnut products $( \pm 35 \%)$, fish (fresh and canned), other agricultural products. Main clients are the EEC, Nigeria, Venezuela and Ivory Coast. 
Total imports amount to $862 \mathrm{mln}$ US $\$(1985)$ of which food is the most important. Main suppliers are the EEC, Nigeria, the USA, Cuba and Ivory Coast.

8. Miscellaneous:

World Bank classification: Senegal belongs to the low-income economies with a GDP per capita of 370 US \$ (1985).

Membership of international organisations:

ECOWAS, GATT, ILO, IMF, OAU, UN, UNESCO, WHO, African Development Bank, African Groundnut Council, Arab Bank for Economic Development in Africa (recipient), Economic Commission for Africa, French Monetary Area, Islamic Conference, Islamic Development Bank, West African Economic Community, World Bank.

Senegal is a signatory to the Lomé Convention (EEC-ACP).

Senegalese Embassy in Belgium: $\quad$ Fr. Rooseveltlaan 196 1050 Brussel

Tel. 02/672.90.51

Belgian Embassy in Senegal: Route de la Corniche Est

B.P. 524

Dakar, Senegal 